\section{OPEN ОACCESS}

DOI 10.25040/ntsh2021.02.24

Для листування: Львівський національний медичний університет імен Данила Галицького, вул. Пекарська 69, м. Львів, 79010,

Е-пошта: ozayachkivska@gmail.com

Стаття надійшла: 01.11.2021

Прийнята до друку: 12.12.2021

Опублікована онлайн: 29.12.2021

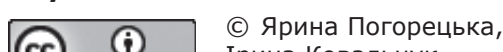
Ірина Ковальчук, Ірина Музика, Ірина

Стрийська, Мар'яна Савицька,

Оксана Заячківська, Василь Лончина, 2021

ORCID IDs:

Ярина Погорецька:

https://orcid.org/0000-0002-1252-0121

Ірина Ковальчук:

https://orcid.org/0000-0001-9700-8399

Ірина Музика:

https://orcid.org/0000-0001-7446-6063

Ірина Стрийська:

https://orcid.org/0000-0001-7262-358X

Мар'яна Савицька:

https://orcid.org/0000-0001-9404-4589

Оксана Заячківська:

https://orcid.org/0000-0002-8792-9204

ВНЕСОК АВТОРIв: Усі автори в однаковій мірі зробили внесок у підготовку рукопису, його редагування а також прочитали та затвердили подану версію.

\section{Інтегративна фізіологія як інструмент для трансформації медичної освіти}

Ярина Погорецька*, Ірина Ковальчук, Ірина Музика, Ірина Стрийська, Мар'яна Савицька, Оксана Заячківська

Львівський національний медичний університет імені Данила Галицького, м. Львів, Україна

Враховуючи швидкий поступ розвитку сучасної науки, сьогодні ключове місце в медичній освіті належить інтегративній фізіології, яка вивчає закономірності функціонування організму людини щодо індивідуальних особливостей з огляду на дію епігенетичних чинників та ендогенні впливи, які спричинюють зміни у клітинних механізмах. На прикладі 5-річного досвіду викладання фізіології у Львівському національному медичному університеті імені Данила Галицького подано значення імплементації у навчання майбутніх лікарів прикладної інтегративної фізіології для трактування фізіологічних явищ, адаптивних механізмів і ресурсів компенсації в організмі людини. Застосування методів оцінювання функцій людини у реальному часі, які ґрунтуються на високоточній реєстрації індивідуальних функціональних особливостях і адаптивних фізіологічних механізмів і мають високу діагностичну значущість, дає змогу сформувати у майбутніх лікарів клінічні компетенції згідно з сучасними засадами медичної науки, персоналізованої медицини та превентивних стратегій оздоровлення.

Ключові слова: фізіологія, інтегративна фізіологія, медична освіта, персоналізована медицина, методи діагностики в реальному часі.

\footnotetext{
* Оприлюднено під час "Поліпшення якості освіти в Україні та ЄC" в ISMA Вища школа менеджменту інформаційних систем" (Латвійська Республіка), 21 червня - 31липня 2021 р.
} 


\section{Integrative Physiology as tool for medical education transformation}

\author{
Yaryna Pohoretska*, Iryna Kovalchuk, Iryna Muzyka, \\ Iryna Stryiska, Maryana Savytska, \\ Oksana Zayachkivska
}

\section{Danylo Halytsky Lviv National Medical University, Lviv, Ukraine}

Given the rapid progress of modern science, integrative physiology holds a key place in medical education, as it studies patterns of human body functioning in terms of individual characteristics, epigenetic factors and endogenous effects on cellular mechanisms. Drawing on five years of experience in teaching physiology at Danylo Halytsky Lviv National Medical University, we highlight the importance of implementing applied integrative physiology in the training of future doctors. We present interpretation of physiological phenomena, adaptive mechanisms and compensation resources in the human body. The introduction of methods for assessing human functions in real time based on high-precision registration of individual functional characteristics and adaptive physiological mechanisms with high diagnostic value, allows future doctors to develop clinical competencies in modern principles of medical science, personalized medicine, and preventive healthcare strategies.

\section{open 2 access}

DOI 10.25040/ntsh2021.02.24

For correspondence: Pekarska st, 69, Lviv, Ukraine, 79010

E-mail: ozayachkivska@gmail.com

Received: Nov, 1, 2020

Accepted: Dec, 11, 2021

Published online: Dec, 29, 2020

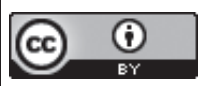

C) Yaryna Pohoretska, Iryna Kovalchuk, Iryna Muzyka, Iryna Stryiska, Maryana Savytska, Oksana Zayachkivska,

ORCID IDs

Yaryna Pohoretska:

https://orcid.org/0000-0002-1252-0121

Iryna Kovalchuk:

https://orcid.org/0000-0001-9700-8399

Iryna Muzyka:

https://orcid.org/0000-0001-7446-6063

Iryna Stryiska:

https://orcid.org/0000-0001-7262-358X

Maryana Savytska:

https://orcid.org/0000-0001-9404-4589

Oksana Zayachkivska:

https://orcid.org/0000-0002-4309-2473

AUTHOR CONTRIBUTIONS: All authors contributed equally to the first draft of the manuscript, manuscript revision, and read and approved the submitted version.

Keywords: physiology, integrative physiology, medical education, personalized medicine, real-time diagnostic methods.

\footnotetext{
* Presented as a lecture during "Quality improvement in medical education of Ukraine and EU", ISMA University of Applied Sciences (Republica Latvia), June 21-July, 31, 2021
} 
Праці НТШ Медичні науки

2021, Том 65, № 2 ISSN 2708-8634 (print)

Актуально

\section{Вступ}

Сьогодні важко уявити роботу сучасного лікаря без інноваційних високотехнологічних інструментів, які ґрунтуються на прогресі наукової думки та інноваціях. Вираз «штучний інтелект одягнув білий халат» влучно демонструє активне використання лікарями автоматизованих і цифрових інструментів реєстрації фізіологічних явищ, процесів та їхніх відхилень у реальному часі $[1,2]$. Серед доклінічних дисциплін, які $\epsilon$ важливим етапом у підготовці майбутніх лікарів і формують необхідні медичні компетенції, практичні навички та клінічне мислення, центральне місце належить дисципліні «фізіологія». Тривалий час загальноприйнятим у вивченні студентами медичних факультетів трактування функцій, фізіологічних процесів, які відбуваються в організмі людини та їхніх параметрів, виконували згідно з емпіричностями та догмами «нормальності». Наприклад, ми часто полягаємо на «людину з підручника» ("textbook person") або «типового пацієнта» зі специфічними типовими характеристиками: чоловік віком 21-25 років, 70 кг ваги, об'єм циркулюючої крові - 7\%, хвилинний об'єм серця - 5 Л/ хв та іншими типовими параметрами. Отже, 3 погляду майбутніх лікарів виключається решта 99,5\% майбутніх пацієнтів $[2,3]$. На думку відомого лідера фізіології David Paterson [4], однією з сучасних стратегій розвитку фізіології з огляду на сучасні глобальні зміни екології та пандемію має стати активне впровадження сучасних наукових знань на передову боротьби з поширенням коронавірусної хвороби (COVID-19), для оздоровлення суспільства та у клінічну практику. Сучасна фізіологія, якої навчають майбутніх лікарів з позицій мультидисциплінарності, має ґрунтуватись на вивченні функціонування організму людини у здоров'ї та під час адаптації до впливу факторів щоденного життя. Іншим важливим аспектом, у відповідності до сучасного рівня наукових досягнень, $\epsilon$ розуміння передумов, які сприятимуть фізіологічним змінам і як це може вплинути на появу хвороби. Адже без сучасних знань, які чітко визначають та аргументують їхнє застосування в практичній клінічній роботі, не відбувся 6 революційний прорив у специфічній профілактиці COVID-19, діагностиці й лікуванні серцево-судинних, гастроентерологічних, пульмонологічних, неврологічних, гематологічних хвороб, раку, безпліддя та багатьох інших недуг.
Proc Shevchenko Sci Soc Med Sci www.mspsss.org.ua ISSN 2708-8642 (online) 2021, Vol. 65, 2 Current news

\section{Перспективність інтегративної фізіоло- гії та сучасні виклики}

У наш час наукове трактування фізіологічних явищ і механізмів їх реалізації опирається на докази, отримані в експериментальних і клінічних дослідженнях (що виконуються in vitro, in vivo, in silico) за допомогою комп'ютерних технологій та штучного інтелекту. Враховуючи швидкий поступ розвитку наук про геном, протеїном [5], гліком, метагеном [6], розвиток сучасних інструментальних і лабораторних методів дослідження, включно з неінвазивними біосенсорами, медичними гаджетами, майбутніх лікарів потрібно ознайомлювати з ними. Адже, виявлення індивідуальних особливостей функціонування організму людини з огляду на вплив епігенетичних чинників, включно зі зовнішнім середовищем і стилем життя, та ендогенних молекулярних сигналів [7] $€$ предметом інтегративної фізіології. Пріоритетне завдання цієї науки - мультидисциплінарні дослідження функціональних систем організму людини щодо нейро-гуморальних, імунологічних і молекулярних механізмів. Крім того, використання новаторських інструментів дає змогу майбутньому лікарю зрозуміти ланцюжок подій між здоров'ям, порушенням адаптивних механізмів, передумовами розвитку хвороби, методами профілактики, діагностики і лікування захворювань. Лише такі фахівці здатні реалізувати в щоденній клінічній чи науковій медичній роботі новітню стратегію охорони здоров'я 4Р (від англ.: Predictive, Preventive, Personalized, and Participatory - прогнозована, превентивна, персоналізована та за участю) [8].

Студентів медиків з перших днів навчання потрібно ознайомлювати з сучасними методами дослідження, які ґрунтуються на високонаукових технологіях, наприклад, як зміни в емоціях можуть викликати відмінності в сигналах електроенцефалографії (ЕЕГ) [9]. Використання численних пристроїв допомагає, в режимі реального часу зареєструвати вікові, статеві відмінності, особливості впливу стилю життя, навколишнього середовища, нейро-гуморальної регуляції та імунної відповіді, $\epsilon$ основою дистанційного моніторингу пацієнтів [10]. Особливо це набуло актуальності у час пандемії коронавірусної хвороби (COVID-19), яка сприяє виникненню і формуванню нових знань 


\section{Introduction}

Today, one can hardly imagine the work of a modern doctor without state-of-the-art tools based on the progress of scientific thought and innovation. The expression "artificial intelligence puts on a white robe" aptly illustrates the active use by doctors of automated and digital tools for recording physiological phenomena, processes and their deviations in real time [1, 2]. Among preclinical disciplines, which are an important stage in the training of doctors and shape their medical competencies, practical skills and clinical thinking, "physiology" takes up a central place. For a long time, the interpretation of physiological processes taking place in the human body and their parameters, generally commonly learned by medical students, was performed following empiricisms and the dogmas of "normality". For instance, often there is a "textbook person" or a "typical patient" with specific typical characteristics: a man aged 2125, weighing $70 \mathrm{~kg}$, circulating blood volume $7 \%$, cardiac output - $5 \mathrm{l} / \mathrm{min}$ and other typical parameters. Thus, from the perspective of doctors in training, $99.5 \%$ of future patients are excluded [3]. According to well-known leaders of physiologists David Paterson [4] contemporary scientific knowledge should be applied in combating the spread of the coronavirus (COVID-19) pandemic. This should be one of the modern strategies to develop physiology in view of current global environmental changes, the pandemic and for the purposes of public health and good clinical practice. Modern physiology, which is taught in a multidisciplinary approach, should be based on the study of the healthy human body functioning and during the adaptation to daily life factors. Another important aspect is to understand preconditions that will contribute to physiological changes and how this may affect the onset of the disease. After all, without modern knowledge that clearly defines and substantiates their use in practical clinical work, there would be no revolutionary breakthrough in the specific prevention of, diagnosis and treatment of COVID-19 infections, cardiovascular, gastroenterological, pulmonary, neurological, hematological diseases, cancer, infertility, and other diseases.

\section{Prospects of integrative physiology and modern challenges}

The scientific interpretation of physiological phenomena and mechanisms of their imple- mentation is based on evidence obtained in experimental and clinical studies (performed in vitro, in vivo, in silico) with the aid of computer technology and artificial intelligence. The rapid development of sciences of the genome, proteome [5], glycome, metagenome [6], modern instrumental and laboratory research methods, including non-invasive biosensors, medical gadgets, endures young medical students to learn them. The subject of integrative physiology is the identification of individual characteristics of the human body, accounting for the influence of epigenetic factors, including the environment and lifestyle, as well as endogenous molecular signals [7]. This science is primarily tasked with multidisciplinary studies of functional systems of the human body against neuro-humoral, immunological and molecular mechanisms. Furthermore, the use of innovative tools helps the future doctor understand the chain of events between health, impaired adaptive mechanisms, preconditions for disease development, methods of disease prevention, diagnosis and treatment. They must learn to implement the latest 4P health strategy (Predictive, Preventive, Personalized, and Participatory) in their daily clinical or scientific medical work [8].

From the first days of study, medical students must be introduced to modern research methods based on highly scientific technologies, e.g., how changes in emotions can affect electroencephalographic (EEG) signals [9]. The use of numerous devices help register age and gender differences, the impact of lifestyle, environmental, neuro-humoral regulation and immune response in real time; it is the basis of remote patient monitoring [10]. This has become especially relevant during the pandemic of coronavirus disease (COVID-19), which contributes to the emergence and development of new knowledge about our body's interactions with the environment. Numerous research centers have been actively studying the impact of this highly contagious infectious disease not only in medical aspects but also in general and individual responses in terms of global and local manifestations associated with many disorders of adaptive responses to new stressors [11]. After all, modern conditions clearly demonstrate that human health is determined by unique physiological capabilities of adaptive mechanisms and compen- 
Праці НТШ Медичні науки

2021, Том 65, № 2 ISSN 2708-8634 (print)

Актуально

про способи взаємодії організму з зовнішнім середовищем. Численні наукові дослідницькі центри активно вивчають вплив цієї інфекційної висококонтагіозної хвороби не лише в медичних аспектах, а й у загальних та індивідуальних реакціях з погляду глобальних і локальних проявів, які пов'язані з низкою розладів адаптивних реакцій до нового стресора [11]. Адже сучасні умови чітко демонструють, що здоров'я людини обумовлено унікальними фізіологічними можливостями адаптивних механізмів і ресурсів компенсації, які ґрунтуються на індивідуальних властивостях функціональних систем, їхніх регуляторних механізмах, що забезпечують реактивність організму та компенсаторну здатність забезпечити гомеостаз у відповідь на дію стресових факторів різного ґенезу.

\section{Досвід використання інтегративної фі- зіології в освіті майбутніх лікарів}

Участь у проекті «Globalization in Medical education» від програми US Fulbright 2016/7 стала продовженням імплементації у підготовку майбутніх лікарів у Львівському національному медичного університеті імені Данила Галицького (ЛНМУ) досвіду світової медичної освіти, яку розпочали 20 років тому [12]. У 2002 році українські студенти медики отримали для користування перший український переклад 20-го видання всесвітньовідомого базового підручника для медичних університетів професора Каліфорнійського університету Вільяма Френсіса Ґанонґа (William Francis Ganong) Review of Medical Physiology. 20th ed. (2001) видавництва Lange Medical Books/ McGraw-Hill [13]. Видання книги фінансував меценат Григорій Малиновський (з Деітройту, Мичиган, США). Вперше майбутні українські лікарі мали змогу зрозуміти глибинні зв'язки фізіології з найновішими відкриттями та здобутками біохімії, морфології, генетики та молекулярної біології. Особливу увагу в підручнику приділено дослідженням молекулярних і генетичних механізмів. Раніше їхнє значення у вітчизняних підручниках ніколи не використовували для трактування фундаментальних питань регулювання функціональних систем організму та їхнього значення в розвитку захворювань. Через 15 років участь у проекті, присвяченому питанням глобалізації медичної освіти, мала на меті імплементувати сучасні навчальні інструменти, які використо-
Proc Shevchenko Sci Soc Med Sci www.mspsss.org.ua ISSN 2708-8642 (online) 2021, Vol. 65, 2 Current news

вують у світовому навчальному просторі для вивчення інтегративної фізіології. Серед них ми обрали три напрями: 1) методи активного навчання, що ґрунтуються на інтерактивному використанні традиційних і цифрових технологій для дослідження у реальному часі функціональних вісцеральних систем для порівняння трактування фізіологічних явищ; 2) ознайомлення з потенціалом сучасних наукових знань і значенням іновативних методів, які мають перспективність для інтегративної фізіології; 3) використання методу конкретних ситуацій (case study), що подають фізіологічний феномен чи окремі ланки фізіологічного механізму з погляду реальних подій або в реальному часі. Такі потужні інструменти навчання допомагають сформувати у майбутніх лікарів необхідні практичні навички та медичні компетенції для майбутньої клінічної практичної діяльності відповідно до сучасних знань з фізіології щодо вікових змін, статевих відмінностей, метаболічних особливостей і розуміння превентивних персоналізованих стратегій оздоровлення. Використання завчасно підготовленого навчального матеріалу, який відображає конкретну проблему, дає змогу проілюструвати майбутньому лікарю зміни фізіологічних процесів, які відбуваються на рівні клітини і в цілому організмі одночасно. Використовування машинневого навчання (machine learning) допомагає відрізнити дилятаційну кардіоміопатію від ішемічної кардіоміопатії, що важливое для точної медицини [14]. Застосування технологій штучного інтелекту в моніторингу плода $€$ корисним для раннього виявлення ранніх порушень патологічного стану плода [15].

Для активного навчання критично важливим і вчасним $€$ ознайомлення студентів медиків з досвідом використання найсучасніших методів дослідження у вісцеральній фізіології, які забезпечують отримання показників 3 високою діагностичної точністю та у довготривалому спостереженні. Для наближення навчання фізіології згідно з засадами глобалізації медичної освіти викладачі кафедри нормальної фізіології ЛнМу підготували сучасну серію студенських навчальних матеріалів, наприклад, з серцево-судинної фізіології [16] та фізіології нирок [17]. На практичних заняттях, адаптивні можливості регуляторних систем організму у динаміці змін та інтеграції можна досліджувати за допомо- 
satory resources, based on individual peculiarities of functional systems, their regulatory mechanisms that ensure the body's response and compensatory ability to ensure homeostasis in response to various stressors.

\section{The experience of using integrative phys- iology in the education of future doctors} The participation in the US Fulbright 2016/7 program "Globalization in Medical education" project has resulted in the implementation of global medical education in the training of doctors at Danylo Halytsky Lviv National Medical University (LNMU). As a prelude, in 2002, Ukrainian medical students received the first Ukrainian translation [12] of the 20th edition of the world-renowned basic textbook for medical universities by William Francis Ganong, Professor of the University of California, Review of Medical Physiology. 20th ed. (2001) published by Lange Medical Books / McGraw-Hill [13]. The publication of this book was funded by the philanthropist Hryhoriy Malynovskyi (from Detroit, Michigan, USA). For the first time, Ukrainian doctors had an opportunity to understand profound connections between physiology and the latest discoveries and achievements in biochemistry, morphology, genetics and molecular biology. The textbook especially focused on the study of molecular and genetic mechanisms. Prior to this introduction of a western text, domestic textbooks never emphasized the importance of interpreting fundamental issues of regulating functional systems of the body and in the development of diseases, which is the basis of integrative physiology. Fifteen years later, participation in this project, focused on the globalization of medical education, aimed to implement modern educational tools used in the global educational space to study integrative physiology.Three areaswere selected: 1) methods of active learning based on the interactive use of traditional and digital technologies for real-time study of functional visceral systems to compare the interpretation of physiological phenomena; 2) review of the potential of modern scientific knowledge and the importance of innovative methods with prospects for integrative physiology; 3) the use of the case study method, which presents a physiological phenomenon or individual parts of the physiological mechanism in terms of real events or in real time. Such powerful learning tools help future doctors develop the required practical skills and medical competencies for clinical practice, modern knowledge of physiology in terms of age changes, gender differences, metabolic characteristics and understanding of preventive personalized recovery strategies. The use of training material prepared in advance, which reflects a specific problem, allows illustrating changes in physiological processes that occur at the cellular level and in the entire body at the same time. As an example, machine learning helps distinguish dilated cardiomyopathy from ischemic cardiomyopathy, which is important for precise medicine [14]. Artificial intelligence technologies in fetal monitoring are useful for detecting early fetal disorders [15].

The review of the experience of using the latest research methods in visceral physiology, which ensure that indicators with high diagnostic accuracy and long-term follow-up are obtained, is critical for medical students' active learning. To bring the teaching of physiology closer to the principles of globalization of medical education at the Department of Normal Physiology at LNMU, a modern series of student teaching materials was prepared, such as resources on cardiovascular physiology [16], kidney physiology [17]. During practical classes, students can explore the adaptive capabilities of the body's regulatory systems in the dynamics of change and integration using RHEO-TEST software (Kharkiv, Ukraine). This allows non-invasive registration of rheoencephalography, rheovasography, rheohepatography, rheopulmonography and rheocardiography simultaneously with heart rate variability (HRV). Integrating the results of regional cerebral, pulmonary, hepatic, coronary and main vessels with HRV, which reflects regulatory effects of the autonomic nervous system and humoral factors, helps determine the impact of regulatory mechanisms on the cardiovascular system in real time (Fig. 1). Having learned such research methods, doctors to be will better understand interrelated aspects of the cardiovascular system functioning and develop competencies for the autonomous regulation of cardiac activity according to individual characteristics (weight, sympathetic, normotony) in healthy people with different levels of physical activity, differences in cellular metabolism. Accord- 
Праці НТШ Медичні науки 2021, Том 65, № 2 ISSN 2708-8634 (print) Актуально

гою комп'ютерного програмного комплексу «RHEO-TEST» (Харків, Україна). Це дає змогу неінвазивно зареєструвати реоенцефалографію, реовазографію, реогепатографію, реопульманографію та реокардіографію у синхронізації з варіабельністю серцевого ритму (BCP). Інтеграція результатів регіонального мозкового, легеневого, печінкового, вінцевого та магістральних судин з ВСР, що відображає регуляторні впливи автономної нервової системи та гуморальних чинників, допомагає з'ясувати вплив регуляторних механізмів на
Proc Shevchenko Sci Soc Med Sci www.mspsss.org.ua ISSN 2708-8642 (online) 2021, Vol. 65, 2

Current news

серцево-судинну систему загалом у режимі реального часу (рис. 1). Ознайомившись 3 такими методами досліджень, майбутні лікарі краще зрозуміють взаємопов'язані аспекти функціонування серцево-судинної системи та сформують компетенції щодо автономної регуляції серцевої діяльності згідно з індивідуальними особливостями (ваго-, симпатико-, нормотонія) у практично здорових людей, які мають різну фізичну активність, відмінності у клітинному метаболізмі. За параметрами ВСР і реографією можна оцінити тип автономної

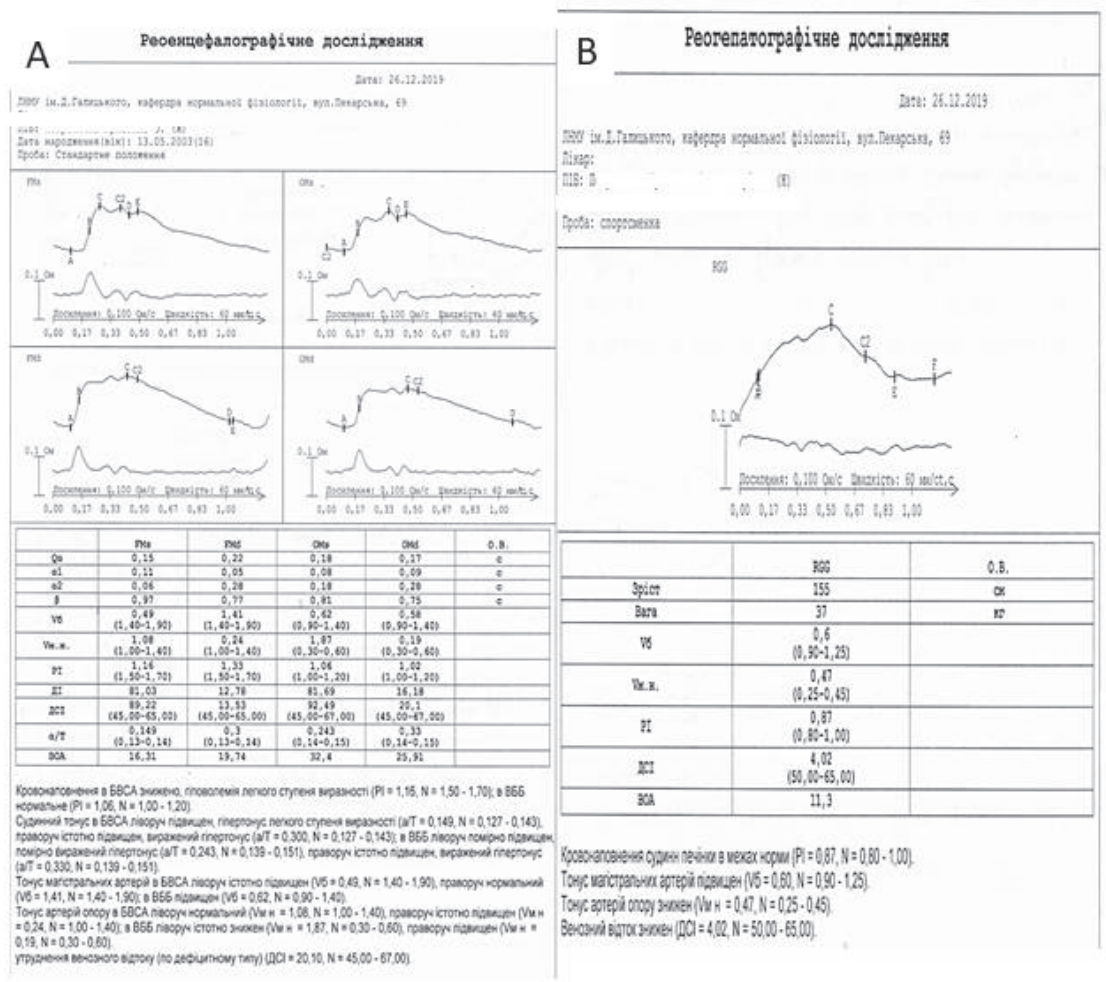

равсторахальне тетраполярне реокардіографічке достірхен C

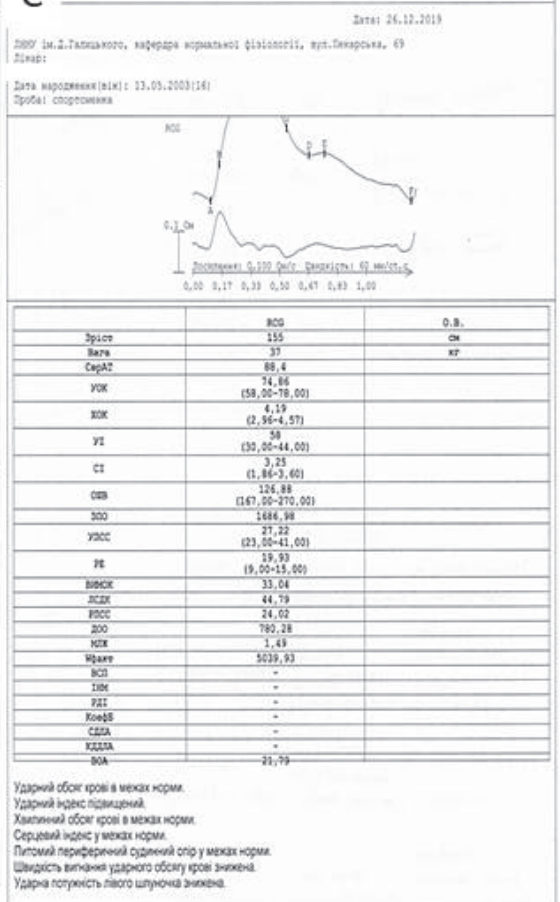

Рисунок 1. Приклад запису особливостей кровообігу з амплітудно-часовими характеристиками та автоматичним описом з урахуванням вікових норм під час реоенцефалографічного (A), реогепатографічного (B) i трансторакального тетраполярного реокардіологічного (C) дослідження за допомогою комп'ютерного програмного комплексу «RHEO-TEST» (Харків, Україна) у здорової жінки юнацького віку без шкідливих звичок з інтенсивною фізичною активністю (А-С - в спортсменки елітного класу з урахуванням ваго-зростових показників. У спортсменки зареєстровано високі значення ударного об'єму крові (УОК), що асоціюється зі значними резервами збільшення хвилинного об'єму крові (ХОК, Cardiac output), що характеризує переважний інотропний вплив на роботу серця. Високий ХОК $\epsilon$ інтегральним показником стану серцево-судинної системи і характеризує рівень кровопостачання тканин та органів, що пов'язане з кисневим запитом. Про це свідчить збільшений ударний індекс (УІ) до 58 (при нормі 30-44), який вказує на еукінетичний тип гемодинаміки. Його трактують, як найбільш економічний, що $є$ важливим для оцінки рівнів навантаження та $€$ показником тренованості організму. Підвищення показника загального периферійного опору (3ПО), що є функцією артеріол і репрезентує особливості нейро-гуморальної регуляції кровоплину в організмі і окремих органах для забезпечення оптимального рівня артеріального тиску, вказує за умов збільшенню кровообігу на рівні капілярів та прискорення току крові по великим судинам, яке виникає за збільшення метаболічних потреб активно працюючих м'язів. Одночасно зареєстровано низький показник питомий периферійний опір судин (ППОС, specific peripheral vascular resistance), що характеризує тонічне напруження судин різного діаметру і одночасне створення сприятливих умов для зростання УI (SVI) серця. Зниження об'ємної швидкості вигнання (ОШВ) свідчить високу ефективність роботи серцевого м'яза та адаптованості серця до фізичного навантаження. Вказані особливості кровообігу відображають економічність фізіологічних функцій та зростання потенційних можливостей для виконання фізичних навантажень 
ing to HRV parameters and rheography, it is possible to assess the type of autonomic regulation, identify preconditions for disorders, early signs of changes in visceral systems, diagnose stress levels, the degree of regulatory system stress, monitor the functional state of the body during normal exercise or systemic functional disorders. Short-term and daily registration of cardio intervals allows conducting a rapid assessment of cardiac activity under the conditions of functional tests and drug exposure. Changes in circadian rhythms of the cardiovascular system can be recorded, which is crucial for timely diagnosis and adequate treatment of patients, evaluation of treatment effectiveness, and a group of patients at high risk of sudden death may be identified.

The learning of innovative non-invasive methods of radiological diagnostics in the study of physiology helps medical students to understand individual peculiarities of changes in the
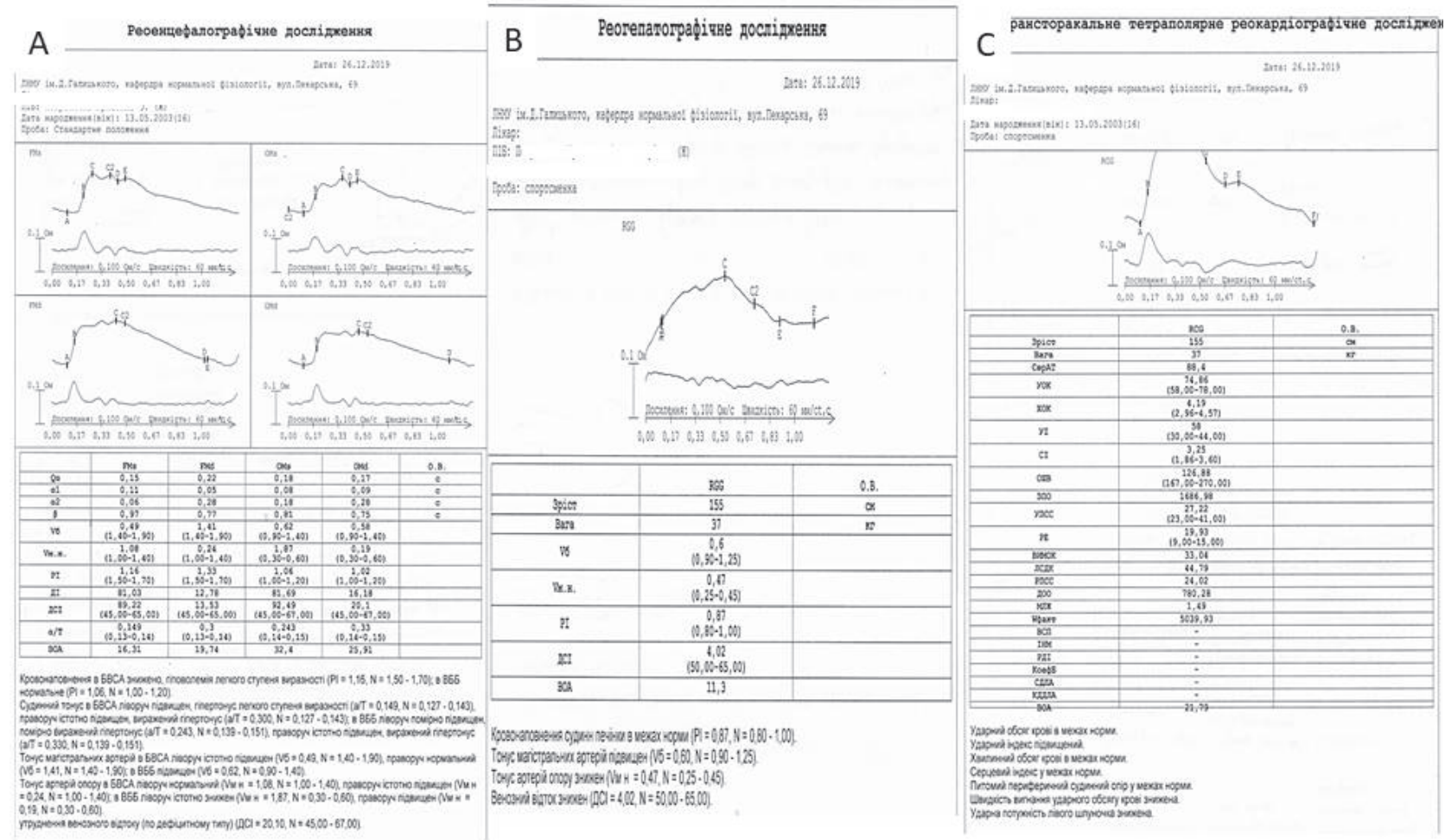

Figure 1. The sample recording of blood circulation peculiarities with amplitude-time characteristics and automatic description considering age norms during rheoencephalographic (A), rheohepatographic (B) and transthoracic tetrapolar rheocardiological (C) research using RHEO-TEST computer software complex (Kharkiv, Ukraine) in healthy young female without harmful habits and with high intensive physical activity (A-C), as in the elite class athlete, taking into account their weight and age. Athlete's registered high values of stroke volume (SV), which is associated with significant reserves of increased cardiac output, which characterizes the predominant inotropic effect on the heart. High cardiac output is an integral indicator of the state of the cardiovascular system and characterizes the level of blood supply to tissues and organs, which is associated with the demand for oxygen. This is evidenced by the increase in stroke volume index (SVI) to 58 (normal - 30-44), which indicates the eukinetic type of hemodynamics. It is interpreted as the most economical, which is essential for assessing load levels and is an indicator of body fitness. The increase in systemic vascular resistance (SVR), which is an arteriole function and represents the peculiarities of neuro-humoral regulation of blood flow in the body and individual organs to ensure optimal blood pressure, in case of increased blood flow, indicates the capillary level and acceleration of blood flow in large vessels, which occurs with the increased metabolic needs of active muscles. At the same time, a low specific peripheral vascular resistance was registered, which characterizes the tonic contraction of vessels of different diameters and the simultaneous creation of favorable conditions for heart SVI growth. The decreased volumetric velocity of ejected blood indicates high efficiency of the heart muscle and adaptation of the heart to exercise. These peculiarities of blood circulation reflect the efficiency of physiological functions and the growth of potential opportunities for exercise. The athlete was diagnosed with a slightly reduced left ventricular stroke power and a reduced rate of stroke volume expulsion, moderate bradycardia. At the same time, an increased rate of stroke volume index was recorded, which can be considered as a constriction of the myocardium's compensatory capacity and the development of adaptive mechanisms caused by exercise. This tension of functional adaptation systems is a consequence of the formed relationship of neuro-humoral mechanisms and revealed reserve capacities of the cardiovascular system to the load. 
Праці НТШ Медичні науки 2021, Том 65, № 2 ISSN 2708-8634 (print) Актуально
Proc Shevchenko Sci Soc Med Sci www.mspsss.org.ua ISSN 2708-8642 (online) 2021, Vol. 65, 2 регуляції, виявити передумови для появи порушень, їхні ранні ознаки щодо змін функціонування вісцеральних систем, діагностувати рівень стресу, ступінь напруження регуляторних систем, контролювати функціональний стан організму за умов нормованих фізичних навантажень або системних функціональних розладів. Можливість короткострокової та добової реєстрації кардіоінтервалів дає змогу провести як експрес-оцінку серцевої діяльності за умов функціональних проб і медикаментозного впливу. Можна зафіксувати зміни циркадіальних ритмів стану серцево-судинної діяльності, що вкрай важливо для своєчасної діагностики й адекватного лікування пацієнтів, оцінювання ефективності лікування, а також виявити групу пацієнтів з високим ризиком раптової смерті.

Імплементація у вивчення фізіології ознайомлення з іновативними неінвазивними методами променевої діагностики допомагає студентам медикам зрозуміти індивідуальні особливості змін нагнітальної функції серця людини з урахуванням віку, статі, зміни реагування за дії стресових факторів різного ґенезу, сформувати практичні навички щодо персоналізованих трактувань діагностичних параметрів. Як приклад, аналіз артеріальної форми хвилі з артерій з використанням нейронних мереж дозволяє швидко та точно визначити зниження тиску в аорті під час коронарографії [18]. Глибоке машинне навчання важливе для створення нових гіпотез про природу біологію гіпертонії [19].

Особливості активності регуляторних систем вісцеральних функцій неспецифічні, тому для вивчення фізіології травлення важливо ознайомити майбутніх лікарів з методами візуалізації травної систем у реальному часі, які ґрунтуються на ендоскопічних методах досліджень. Для цього приготовлено посібник «Фізіологія системи травлення» [20]. Такі методи дослідження мають високу доказовість оцінювання для функціональних і органічних порушень. Специфічно, штучний інтелект точно виявляє злоякісні ураженняь верхніх відділів шлунково-кишкового тракту [21], є основою розуміння появи розладів секреторної та рухової діяльності травної системи і для розробки профілактично-лікувальних заходів гастроентерологічних захворювань [22].

Спільно з курсом за вибором «Молекулярна фізіологія та біотехнології» студентів медиків залучають до додаткової позааудиторної діяльності, яку здійснює осередок Фізіологічного товариства Великобританії (The Physiological Society) у ЛНМу (2015-2021). Товариство провадить щорічні наукові семінари DSS (2016-2021). Члени лікарської комісії Наукового Товариства імені Шевченка, провівши міжнародні симпозіуми SMART LION (2017-2021) [23-25], допомагають майбутнім лікарям сформувати необхідні компетенції та практичні навички, клінічне мислення щодо вимог сьогодення та стратегії розвитку охорони здоров'я 4Р.

Підсумовуючи, можемо стверджувати про важливість імплементації засад інтегративної фізіології у навчання майбутніх лікарів, а також позааудиторна робота що дає змогу краще зрозуміти закономірності життєдіяльності організму людини та сформувати необхідні медичні компетентності відповідно до викликів часу.

\section{References}

1. Liang M. Integrative pathway knowledge bases as a tool for systems molecular medicine. Physiol genomics. 2007;30(3):209-212. doi:10.1152/physiolgenomics.00002.2007

2. https://nrfu.org.ua/news/shtuchnyj-intelekt-u-likarskomu-halati/

3. Rogers KM, Boyle D, Bennett K, Bennett M, Torrens C. Diversifying the case study: How far has physiology education come in integrating equality, diversity and inclusion into the curricula? Physiology. 2021(123):28-31. doi:10.36866/pn.123.28

4. Paterson D. Launch of The Society's new blue plaque scheme. Physiology News. 2021;123: 6. https:// www.physoc.org/magazine-articles/presidents-view-launch-of-the-societys-new-blue-plaque-scheme/

5. Williams AM, Liu Y, Regner KR, Jotterand F, Liu P, Liang M. Artificial intelligence, physiological genomics, and precision medicine. Physiol Genomics. 2018;50(4):237-243. doi:10.1152/physiolgenomics.00119.2017

6. Lin Y, Wang G, Yu J, Sung JJY. Artificial intelligence and metagenomics in intestinal diseases. J Gastroenterol Hepatol. 2021;36(4):841-847. doi:10.1111/jgh.15501 
person's cardiac output considering their age, sex, changes in responses to various stressors, to develop practical skills for personalized interpretations of diagnostic parameters. For example, the analysis of the shape of the wave of arteries using neural networks quickly and accurately determines a drop in aortic pressure during coronary angiography [18]. Deep learning is important for creating new hypotheses about the nature of hypertension [19].

Peculiarities of the activity of regulatory systems of visceral functions are non-specific, so to study the physiology of digestion, it is important that doctors be taught methods for visualizing the digestive system in real time, based on endoscopic research methods. Of great importance is to have the proper textbooks, such as the "Physiology of the digestive system" [20]. Such research methods have high evidence of evaluation for functional and organic disorders. Artificial intelligence accurately detects malignant lesions of the upper gastrointestinal tract [21], it is the basis for understanding disorders of secretory and motor activity of the digestive system and for the development of measures to prevent and treat gastrointestinal diseases [22].

Along with the elective course "Molecular Physiology and Biotechnology", medical students are involved in additional extracurricular activities carried out by the local branch of the Physiological Society of Great Britain at the LNMU (2015-2021) [23-25]. The Society conducts annual DSS scientific seminars (2016-2021). Having held SMART LION international symposia (2017-2021), members of the Medical Commission of the Shevchenko Scientific Society help future doctors develop necessary competencies and practical skills, clinical thinking on current requirements and 4P health care development strategy.

To conclude, we can assert the importance of implementing the principles of integrative physiology in the educational programs of future doctors, as well as extracurricular work which allows us to better understand the laws of the human body and develop the required medical competencies in accordance with the challenges of the time.

7. Rush B, Celi LA, Stone DJ. Applying machine learning to continuously monitored physiological data. J Clin Monit Comput. 2019;33(5):887-893. doi:10.1007/s10877-018-0219-z

8. Sagner M, McNeil A, Puska P, et al. The P4 health spectrum - a predictive, preventive, personalized and participatory continuum for promoting healthspan. Prog Prevent Med. 2017;59(5):506-521. doi: $10.1097 / \mathrm{pp} 9.0000000000000002$

9. Liu H, Zhang $Y$, Li Y, Kong X. Review on Emotion Recognition Based on Electroencephalography. Front Comput Neuroscience. 2021:84;758212. doi:10.3389/fncom.2021.758212

10. Halamka J, Cerrato P. The digital reconstruction of health care. NEJM Catalyst Innovat Care Delivery. 2020;1(6). doi:10.1056/cat.20.0082

11. Alimadadi A, Aryal S, Manandhar I, Munroe PB, Joe B, Cheng X. Artificial intelligence and machine learning to fight COVID-19. Physiol Genomics. 2020; 52:200-202. doi:10.1152/ physiolgenomics.00029.2020

12. Valuieva L. Ukrainskoiu movoiu vyishov drukom pidruchnyk dlia studentiv "Fiziolohiia Liudyny" vidomoho amerykanskoho vchenoho Viliama F. Hanonha. Ukrinform. 11.11.2002. https://web.archive. org/web/20160810005010/http://www.ukrinform.ua/rubric-politycs/106047-ukranskoyu_movoyu_ viyshov_drukom_pdruchnik_dlya_studentv_medikv_fzologya_lyudini_vdomogo_amerikanskogo_ vchenogo_vlyama_fganonga_81666.html

13. Ganong WF. Fiziolohiya lyudyny: Pidruchnyk /Pereklad z anhl. Nauk. red. perekladu Hzhehotskyi M, Shevchuk V, Zayachkivska O. Lviv : BaK, 2002. - 784 pp. - ISBN 966-7065-38-3.

14. Alimadadi A, Manandhar I, Aryal S, Munroe PB, Joe B, Cheng X. Machine learning-based classification and diagnosis of clinical cardiomyopathies. Physiol Genomics. 2020;52(9):391-400. doi:10.1152/ physiolgenomics.00063.2020

15. Signorini MG, Pini N, Malovini A, Bellazzi R, Magenes G. Integrating machine learning techniques and physiology based heart rate features for antepartum fetal monitoring. Comput Methods Progr Biomedicine. 2020;185:105015. doi:10.1016/j.cmpb.2019.105015

16. Kovalchuk IM, Kupynyak NI, Savytska MY. Physiology of cardiovascular system. Handbook for practical lessons for students of the Medical Faculty / Ed. Zayachkivska OS. Danylo Halytsky Lviv National Medical University, 2017. - 82 p. 
17. Pohoretska YO, Kupynyak NI, Savytska MY. Physiology of renal physiology. Methodical instructions for practical lessons for students of medical faculty. / Ed. Zayachkivska OS. Danylo Halytsky Lviv National Medical University, 2017. - 32 p.

18. Howard JP, Cook CM, van de Hoef TP, et al. Artificial intelligence for aortic pressure waveform analysis during coronary angiography: machine learning for patient safety. JACC: Cardiovasc Intervent. 2019;12(20):2093-2101. doi:10.1016/j.jcin.2019.06.036

19. Mueller FB. AI (artificial intelligence) and hypertension research. Curr Hyperten Report. 2020;22(9):70. doi: $10.1007 /$ s11906-020-01068-8

20. Bezpalko LY, Savytska MY, Kupynyak NI. Physiology of digestive system. Handbook for practical classes for students of the medical faculty. Ed. Zayachkivska OS. Danylo Halytsky Lviv National Medical University, 2017. 72pp.

21. Lui TK, Tsui VWM, Leung WK. Accuracy of artificial intelligence-assisted detection of upper GI lesions: a systematic review and meta-analysis. Gastrointest Endosc. 2020;92(4):821-830. doi:10.1016/j. gie.2020.06.034

22. Sinonquel P, Eelbode T, Bossuyt $P$, Maes F, Bisschops R. Artificial intelligence and its impact on quality improvement in upper and lower gastrointestinal endoscopy. Digest Endosc. 2021;33(2):242-253. doi:10.1111/den.13888

23. Szabo S. Protection of T-lymphocytes via PD-1 receptor: New molecular mechanism of cancer immunotherapy. Proc Shevchenko Sci Soc Med Sci. 2019;57(2). DOI: https://doi.org/10.25040/ ntsh2019.02.01

24. Havryluk A, Muzyka I. Chronicles of the second half of 2019 - SMART LION 2019. Proc Shevchenko Sci Soc Med Sci [Internet]. 2019;57(2). Available from: https://mspsss.org.ua/index.php/journal/article/view/249

25. Danylyak O, Stryiska I. 4th SMART LION 2020 COVID-19: Reality and prognosis. Proc Shevchenko Sci Soc Med Sci [Internet]. 2020;62(2). DOI: 10.25040/ntsh2020.02.03 